\title{
Advantages of Tonsillectomy done under Local Anesthesia compared to General Anesthesia in Adults
}

\author{
Sudhir M Naik, Sarika S Naik, S Ravishankara, Mohan K Appaji, MK Goutham \\ Nonthombam Pinky Devi, Annapurna S Mushannavar
}

\begin{abstract}
Background/Objectives: Tonsillectomy using local anesthesia (local tonsillectomy) is a safe and effective alternative to general anesthesia in the healthy cooperative teenage or adult patients. Blood loss, morbidity, complications and patient satisfaction were better in some studies with tonsillectomies done under general anesthesia.
\end{abstract}

Design: Comparative case series analysis study of two groups of patients who underwent tonsillectomies under local and general anesthesia during the study period of 57 months from March 2007 to December 2011.

Materials and methods: Overall 1,349 cases of tonsillectomies done for chronic tonsillitis were included under the study. Three hundred and sixty-seven cases operated under general anesthesia and 982 cases operated under local anesthesia were compared. The parameters compared were duration of surgery, blood loss and the mean pain visual analog score.

Results: Significant difference in duration of surgery, blood loss during surgery and visual analog scale (VAS) pain scores were seen in the two groups with local anesthesia scoring over general anesthesia.

Conclusion: Tonsillectomy under local anesthesia is a good alternate for the procedure under general anesthesia with limited resources and in cooperative adults.

Keywords: Tonsillectomy, Local anesthesia, General anesthesia, Scalpel cautery method.

How to cite this article: Naik SM, Naik SS, Ravishankara S, Appaji MK, Goutham MK, Devi NP, Mushannavar AS. Advantages of Tonsillectomy done under Local Anesthesia compared to General Anesthesia in Adults. Int J Head Neck Surg 2013;4(1):13-18.

Source of support: Nil

Conflict of interest: None declared

\section{INTRODUCTION}

Tonsillectomy is one of the most frequently performed procedures in the Department of Otolaryngology. ${ }^{1}$ Chronic tonsillitis is the most common indications for tonsillectomy followed by peritonsillar abscess and sleep apnea syndrome. ${ }^{2,3}$

In India, chronic tonsillitis remains the most common indication and the dissection method of tonsillectomy is considered the most common and safest method widely practiced. ${ }^{4}$ The classical dissection snare tonsillectomy has been modified over the years and alternate procedures like electrocautery, laser, coblation, bipolar scissors tonsillectomy and radiofrequency ablation have been introduced. $^{5}$
Tonsillectomy using local anesthesia (local tonsillectomy) is a safe and effective alternative to general anesthesia in the healthy cooperative teenage or adult patient. ${ }^{6}$ In India most of the tonsillectomies are done under general anesthesia but cases under local anesthesia are also widely practiced because of economic considerations and long waiting lists. ${ }^{4}$

It is widely accepted that local tonsillectomy needs lesser time, lesser blood loss and lesser costs to the patient. ${ }^{6}$ In our study, we have performed 1,114 tonsillectomies under general and local anesthesia and the results in term of duration, blood loss and pain were compared. All these surgeries under local anesthesia were performed in cooperative adults. Postoperative opinion of many patients revealed they were satisfied by the procedure and would recommend and choose local anesthesia again.

\section{MATERIALS AND METHODS}

This is a comparative case series analysis study of two groups of patients who underwent tonsillectomies under general and local anesthesia. Overall, 1,349 tonsillectomies done for chronic tonsillitis were included under the study with 367 cases done under general anesthesia and 982 cases done under local anesthesia. The cases were operated during the study period of 57 months from March 2007 to December 2011. Ethical committee clearance was obtained from the institution.

The study included 771 males and 578 females. General anesthesia group had 192 males and 175 females with the youngest being 18 years female and the oldest being 47 years male. Local anesthesia group included 579 males and 403 females with the youngest being 19 years male and the oldest being 47 years female. Patients younger than 18 years, tonsillectomies done for other indications than chronic tonsillitis were excluded from the study (Graph 1).

Twenty-three patients were operated using newer tissue welding method, three using harmonic scalpel, seven using coablation method were also excluded. All apprehensive patients were operated under general anesthesia and the rest under local anesthesia. A detailed history was taken and the procedure of surgery was explained to the patients with written consent. A week long antibiotics orally were given to reduce the acute infection in the tonsil if present. All cases were taken for surgery 1 week after antibiotics.

The procedures were done under local and general anesthesia under dissection scalpel cautery method by a 


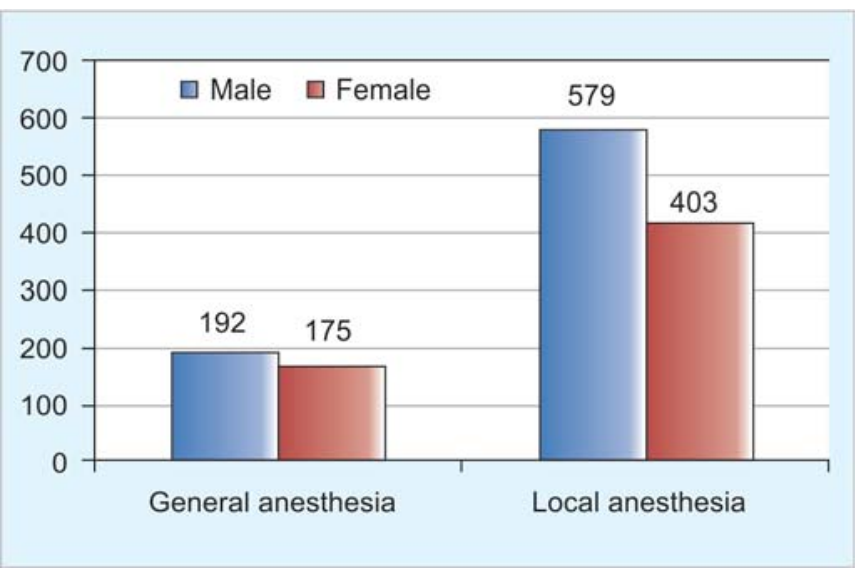

Graph 1: Sex distribution in general and local anesthesia group

single surgeon. Baseline investigations which included full blood count, coagulation values (clotting time, bleeding time) and electrocardiography (ECG) were analyzed. Patients with systemic diseases like hypertension, thyroid toxicity, asthma, diabetes, heart disease, hemorrhagic tendency, neurological disease and allergy to local anesthesia or adrenaline were excluded.

General anesthesia was given with oronasal or orotracheal intubation in 367 cases. In the 982 cases operated under local anesthesia $1 \%$ lidocaine and adrenaline $1: 2,00,000$ was used. In the local group premedication with atropine $0.6 \mathrm{mg}$ and pentazocine $50 \mathrm{mg}$ IV diluted in $10 \mathrm{cc}$ of distilled water were given half an hour before surgery. All patients received four puffs of $7.5 \mathrm{mg} /$ metered dose of lidocaine spray $15 \%(100 \% \mathrm{w} / \mathrm{w})$ immediately before local infiltration. Equal amounts of local anesthesia $(7-10 \mathrm{ml}$ on either side) were infiltrated to the upper middle and lower pole of the tonsils and to the posterior arch (Figs 1 and 2).

Nine hundred and eighty-two patients (579 males, 403 females) were infiltrated by $1 \%$ lidocaine:adrenaline 1:2,00,000. Lidocaine infiltration dose was calculated as 5 $\mathrm{mg} / \mathrm{kg}$ BW. The time from infiltration of the tonsil to the time of grasping the tonsils without pain was taken as time of onset of action of the local anesthetic. It was immediate for $1 \%$ lidocaine. Subcapsular removals of the tonsils with bipolar cautery of the small bleeders were done and larger bleeders were ligated by 3-0 silk threads (Figs 3 and 4).

Operative time for general anesthesia was taken from the time of induction to the time of getting back the swallowing reflex. In local anesthesia it was taken from the time of infiltration to the time the patient sat up and gargled the throat. In local tonsillectomy after the surgery the patient was made to sit and clear his throat with warm diluted $\mathrm{H}_{2} \mathrm{O}_{2}$ and povidine-iodine (Figs 5 and 6).

Intraoperative bleed was measured by calculating difference in weight of blood-soaked guaze pieces before and after surgery plus the amount of blood collected in the suction jar. The weight of the saline sucked in was deducted
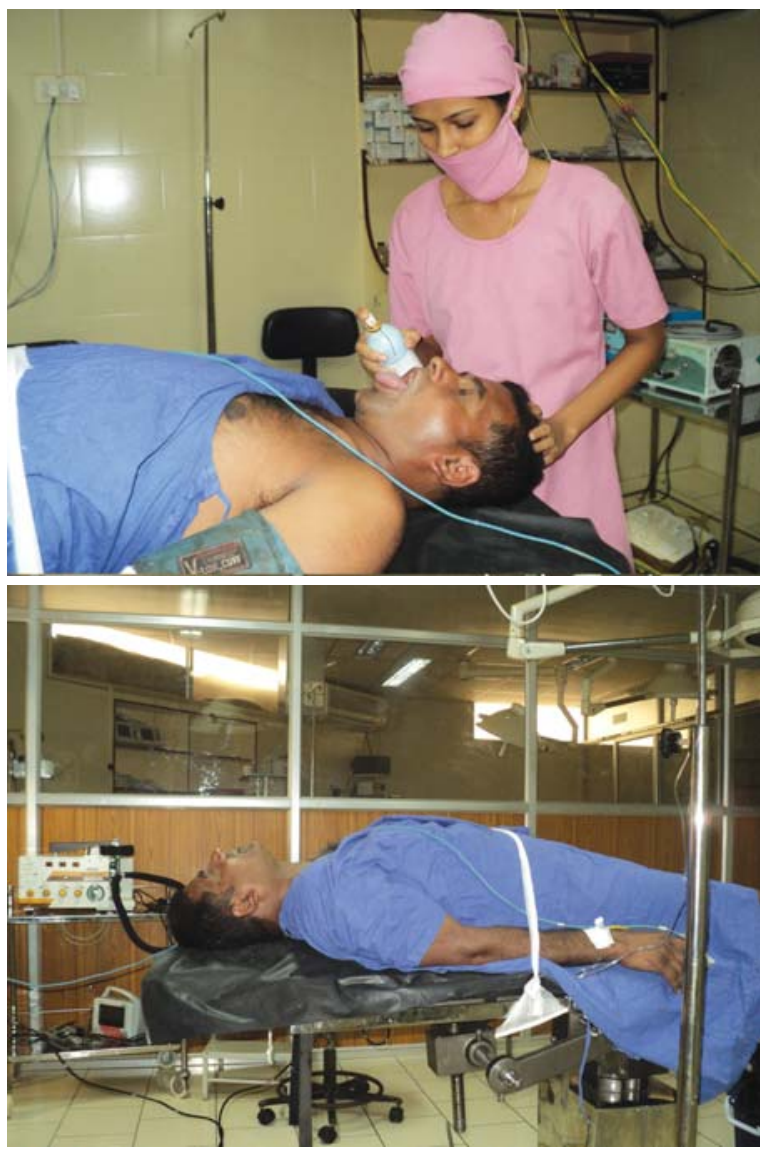

Fig. 1: Fifteen percent local anesthesia spray being used and Rose position given
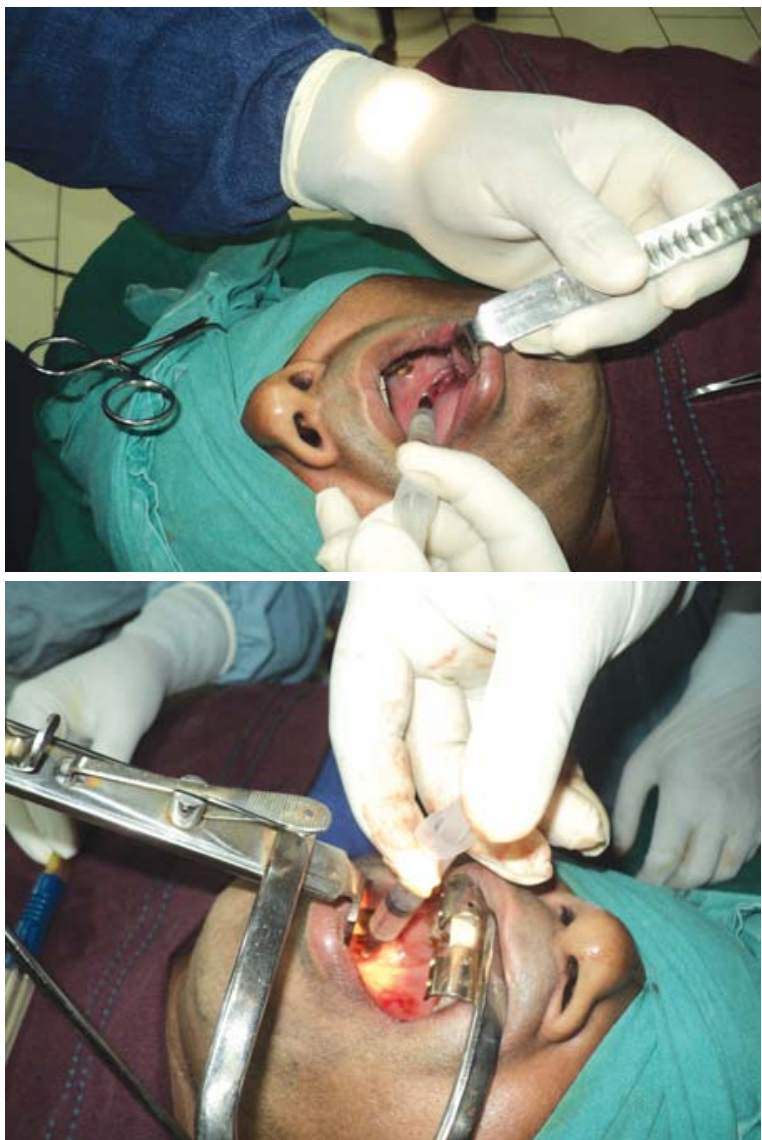

Fig. 2: Infiltrative anesthesia 1\% lidocaine given 

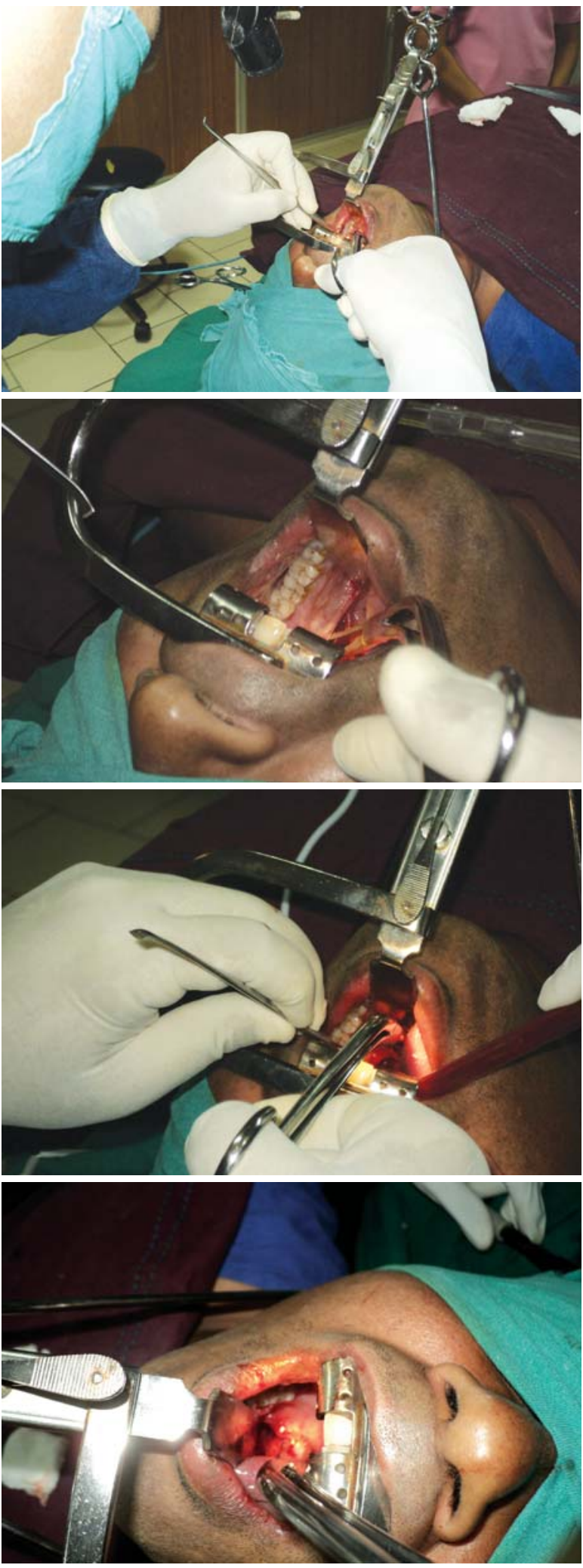

Fig. 3: Dissection snare method of tonsillectomy being done

from the total. Pain sensations were measured by visual analog scale (VAS) at 6, 10, 18 and 24 hours after surgery and the average recorded (Graph 2).

\section{RESULTS}

No unusual complications were reported in the study. Hypersensitivity to lidocaine was not seen in any of the
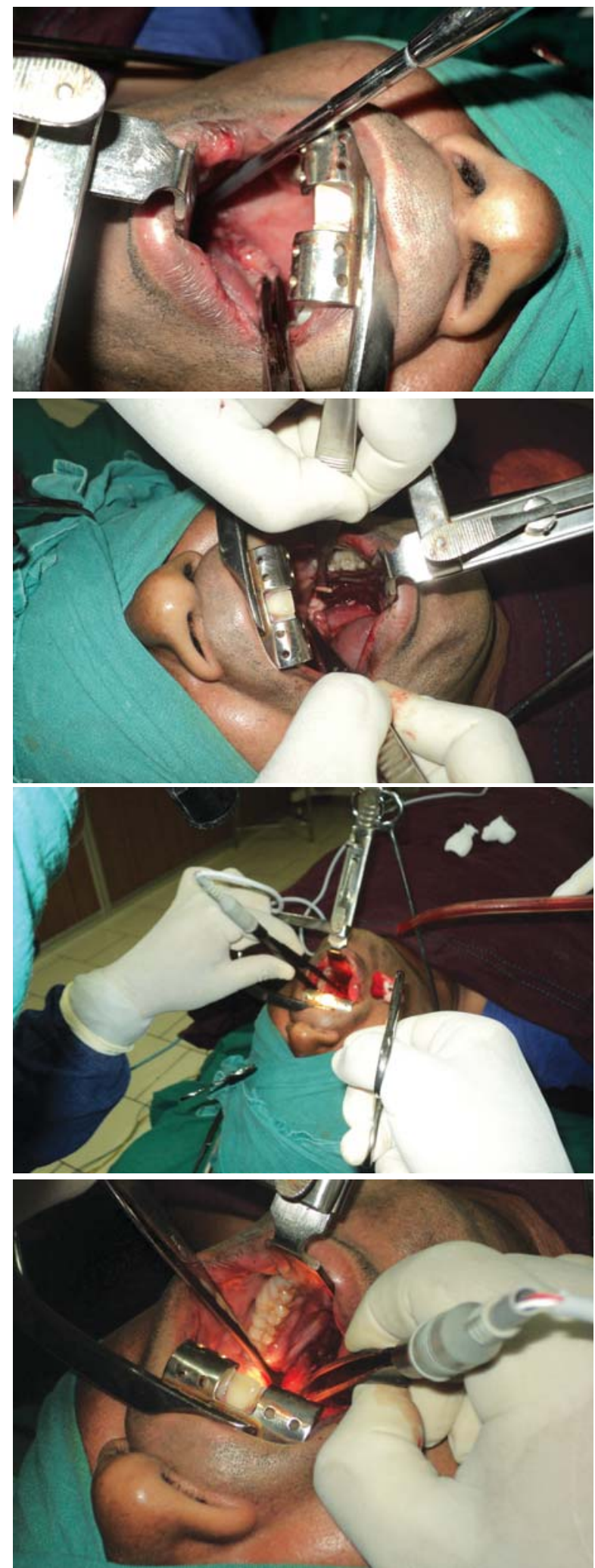

Fig. 4: Tonsils being snared out and bipolar cautery being used

patients. In general anesthesia group mean duration of surgery in males was 50.06 minutes, in females 50.10 minutes, mean age in males was 21.37 years, in females was 21.54 years, mean blood loss in males was $44.43 \mathrm{ml}$, in females $43.36 \mathrm{ml}$.

The VAS scores in males were 4.69, 4.11, 3.876 and 3.612 at $6,10,18$ and 24 hours respectively. While the VAS scores in females were 4.589, 4.294, 4.083 and 3.794 at 6, 

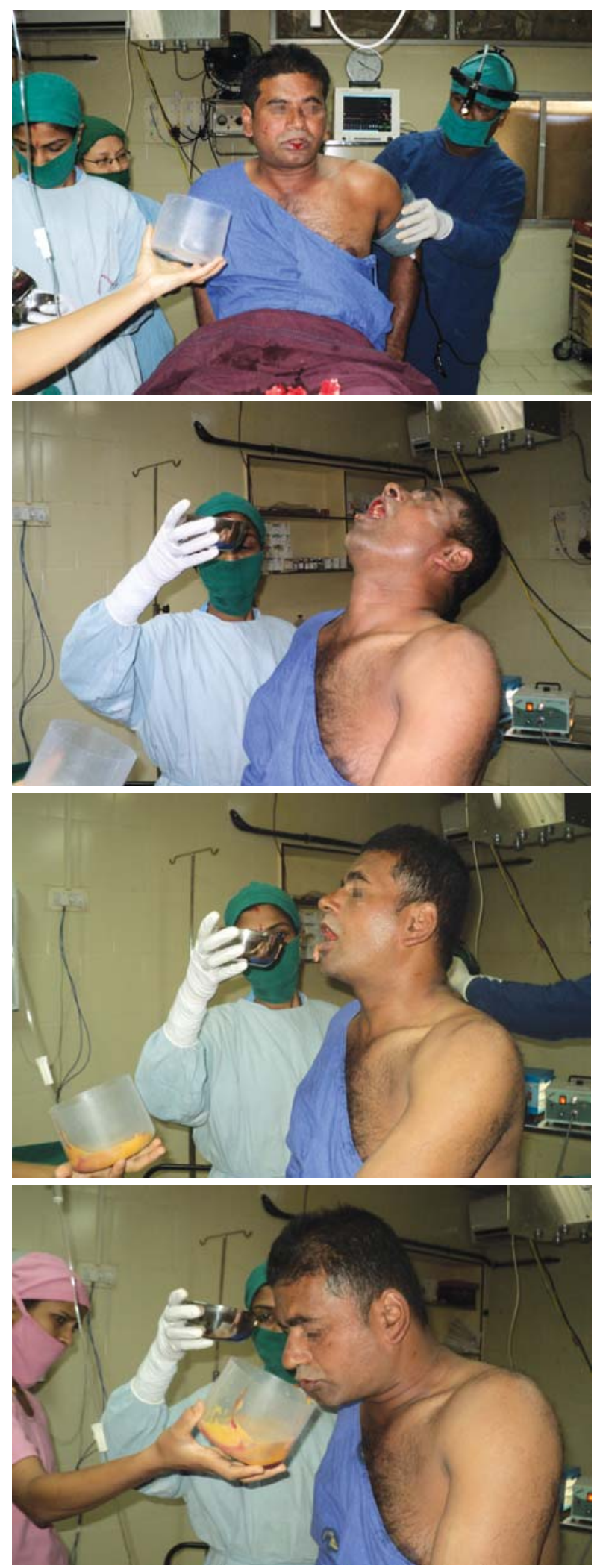

Fig. 5: Hydrogen peroxide and betadine gargling being given immediately after surgery

10, 18 and 24 hours respectively. In local anesthesia group mean duration of surgery in males was 35.34 minutes, in females 35.269 minutes, mean age in males was 25.14 years, in females it was 26.25 years, mean blood loss in males was $29.86 \mathrm{ml}$, in females $30.16 \mathrm{ml}$.

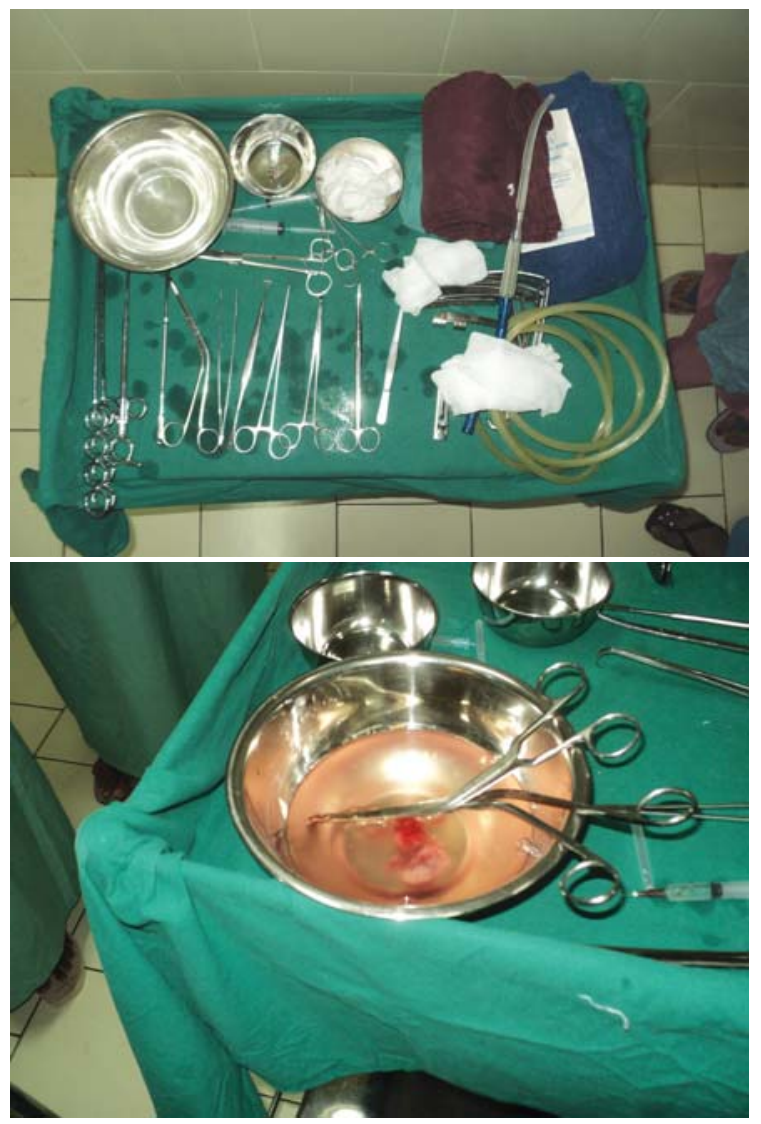

Fig. 6: Instruments used for local tonsillectomy

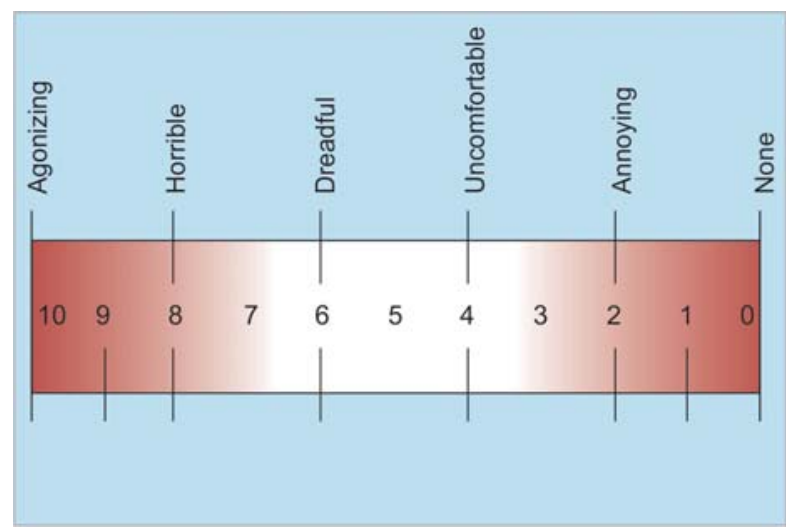

Graph 2: Visual analog scale

The VAS scores in males were 1.7, 3.155, 3.09 and 3.612 at $6,10,18$ and 24 hours respectively. While the VAS scores in females were 1.69, 3.165, 3.106 and 3.586 at 6, 10, 18 and 24 hours respectively. A significant reduction in duration of surgery and blood loss was seen in local anesthesia group compared to general anesthesia group. Also significant low VAS scores were seen in local anesthesia group compare to general anesthesia group (Table 1).

Postoperative nil by mouth was maintained for only 2 hours in local tonsillectomy while 6 hours strictly for tonsillectomy under general anesthesia. All the local anesthesia patients were discharged on 2nd postoperative 
Advantages of Tonsillectomy done under Local Anesthesia compared to General Anesthesia in Adults

Table 1: Average scores of various parameters and their significance values

\begin{tabular}{|c|c|c|c|c|c|c|c|c|}
\hline & & \multirow{2}{*}{$\begin{array}{l}\text { Average } \\
\text { age } \\
\text { (yrs) }\end{array}$} & \multirow{2}{*}{$\begin{array}{l}\text { Duration of } \\
\text { surgery } \\
\text { (min) }\end{array}$} & \multirow{2}{*}{$\begin{array}{l}\text { Blood loss } \\
\text { at surgery } \\
(\mathrm{ml})\end{array}$} & \multicolumn{4}{|c|}{ VAS } \\
\hline & & & & & $6 \mathrm{hrs}$ & $10 \mathrm{hrs}$ & $18 \mathrm{hrs}$ & 24 hrs \\
\hline $\begin{array}{l}\text { General } \\
\text { anesthesia }(n=334)\end{array}$ & $\begin{array}{l}\text { Males } 192 \\
\text { Females } 175 \\
\text { Total } 367\end{array}$ & $\begin{array}{l}21.37 \\
21.54 \\
21.455\end{array}$ & $\begin{array}{l}50.06 \\
50.10 \\
50.08\end{array}$ & $\begin{array}{l}44.43 \\
43.36 \\
43.93\end{array}$ & $\begin{array}{l}4.69 \\
4.589 \\
4.637\end{array}$ & $\begin{array}{l}4.11 \\
4.294 \\
4.197\end{array}$ & $\begin{array}{l}3.876 \\
4.083 \\
3.97\end{array}$ & $\begin{array}{l}3.612 \\
3.794 \\
3.69\end{array}$ \\
\hline $\begin{array}{l}\text { Local } \\
\text { anesthesia }(n=780)\end{array}$ & $\begin{array}{l}\text { Males } 579 \\
\text { Females } 403\end{array}$ & $\begin{array}{l}25.140 \\
26.25\end{array}$ & $\begin{array}{l}35.34 \\
35.269\end{array}$ & $\begin{array}{l}29.86 \\
30.16\end{array}$ & $\begin{array}{l}1.70 \\
1.69\end{array}$ & $\begin{array}{l}3.155 \\
3.165\end{array}$ & $\begin{array}{l}3.09 \\
3.106\end{array}$ & $\begin{array}{l}3.612 \\
3.586\end{array}$ \\
\hline & Total 982 & 25.67 & 35.30 & 30.006 & 1.697 & 3.16 & 3.101 & 3.6 \\
\hline
\end{tabular}

day and all the general anesthesia cases were discharged on the 3rd postoperative day.

\section{DISCUSSION}

Palatine tonsils are lymphatic tissues of the digestive tract epithelium and are present on the lateral wall of the throat that compose the bulk of the so called Waldeyer's lymphatic ring. ${ }^{7,8}$ They are covered by stratified nonkeratinous epithelium, which is an extension of the oral pharyngeal tissue. ${ }^{7,8}$ The epithelium forms about 30 deep crypts that invaginate into the parenchyma in which the lymph nodes are found with the germ centers responsible for B-lymphocyte production. ${ }^{7,9}$

Also found are debris of epithelial cells desquamations, alive and dead lymphocytes, as well as bacterium may be present in the crypts. ${ }^{10}$ The tonsils are enclosed by fibrous and dense capsule, separating them from the deeper connective tissue. ${ }^{7,8}$ Tonsils arise from the second pair of pharyngeal pouches, where the endodermis bears the covering epithelium and the mesenchymal structures give origin to the lymphoid tissue. ${ }^{11}$

Tonsillectomy is one of oldest surgical procedures, described for about 2000 years, by Celso Cornelio in 50 AD. ${ }^{1,12}$ Worthington in 1907 described modifications in technique and first described tonsillar dissection. ${ }^{1,12}$ Whillisy and Pybus in 1910 described Guillotine cutter method of tonsillectomy ${ }^{1,12}$ and Sluder in 1911 described the Sluder-Ballenger's technique of tonsillectomy. ${ }^{13}$ Waugh described the modern method of tonsillectomy by dissection and snare method at the end of 20th century by modifying the Worthington technique. ${ }^{14,15}$

The purpose of tonsillectomy is the complete removal of the palatine tonsils with minimal blood loss while avoiding unnecessary trauma to adjacent tissue. ${ }^{16}$ Despite the fact that advances in modern general anesthetic techniques have lessened risks, but it has increased the cost of surgery. ${ }^{16}$ Tonsillectomy using local anesthesia (local tonsillectomy) is a safe and effective alternative to general anesthesia in the healthy cooperative teenage or adult patient. ${ }^{6}$ Blood loss, morbidity, complications and patient satisfaction were reviewed and compared with tonsillectomies done under general anesthesia. ${ }^{6}$ With local anesthesia the operation required less time, produced less intraoperative hemorrhage and was less costly. ${ }^{16}$ However, there was no significant difference in the incidence of postoperative complications or morbidity. ${ }^{16}$ Post-tonsillar hemorrhage is a dreaded life-threatening complication for a tonsillectomy procedure. ${ }^{6}$ In a retrospective study by Bredenkamp et al, including 64 tonsillectomies done over 7 years, the average blood loss was $42 \mathrm{ml}$ in the local tonsillectomy group, compared with $198 \mathrm{ml}$ in the general anesthesia group. ${ }^{6}$

Pain is the most significant obstacle to the rehabilitation of a patient following tonsillectomy. ${ }^{4}$ Inadequate analgesia causes poor oral intake, which leads to lassitude, delayed recovery of the patient. ${ }^{4}$ Various strategies for the management of post-tonsillectomy pain have been proposed like infiltration of local anesthetic in the tonsillar fossa, ${ }^{17,18}$ intramuscular nonsteroidal anti-inflammatory drugs, ${ }^{19}$ narcotics and oral analgesics. ${ }^{20}$ Application of sucralfate as a protective barrier following tonsillectomy has been found to promote healing with significant pain reduction in the postoperative period. ${ }^{21}$ Use of transcutaneous electric nerve stimulation (TENS) for post-tonsillectomy pain has shown promising results. ${ }^{22}$

McClairen et al in their study on 73 patients found local tonsillectomies to be of significantly less duration, less costly, less intraoperative hemorrhage and no significant difference in postoperative hemorrhage or patient acceptance. ${ }^{16}$ Kennedy et al in their study on 237 patients found higher incidence (15\%) of postoperative bleeding under general anesthesia compared to (3\%) under local anesthesia. ${ }^{23}$ Also reduced cost, lesser operative time and pain were seen in local anesthesia group.

\section{CONCLUSION}

In our study local tonsillectomy required less time, produced less intraoperative hemorrhage and was less costly. We did not see any significant difference in the incidence of postoperative complications or morbidity. We conclude that 
local tonsillectomies have high patient acceptance in adult population and are associated with minimal morbidity and complications. Furthermore, they are cost-effective and can be taken as a day care surgery in setups with economic considerations.

\section{REFERENCES}

1. Kaiser AD. Children's Tonsils in or out? A critical study of the end results of tonsillectomy. Philadelphia: JB Lippincott 1932;7: 2-10.

2. Blum DJ, Neel HB 3rd. Current thinking on tonsillectomy and adenoidectomy. Compr Ther 1983;12:48-56.

3. Bluestone CD. Current indications for tonsillectomy and adenoidectomy. Ann Otol Rhinol Laryngol 1992;155(Supp): 58-64.

4. Gupta AK, Sunanda Gupta, Dharam: Post-tonsillectomy pain: different modes of pain relief. Indian J Otolaryngol Head Neck Surg 2002 April-June;54(2).

5. Laing MR, McKerrow WS. Adult tonsillectomy. Clin Otolaryngol 1991;16:21-24.

6. Bredenkamp JK, Abemayor E, Wackym PA, Ward PH. Tonsillectomy under local anesthesia: A safe and effective alternative: Am J Otolaryngol 1990 Jan-Feb;11(1):18-22.

7. Junqueira LC, Carneiro J. Histologia basica (9th ed). Rio de janeiro: Guanabara Koogan; 242-43.

8. Dolci JEL, et al. Analise histological de 24 tonsilas faringeas de pacientes submetidos a adenoidectomia ou a adenoamigdalaectomia. Rev Bras Otorrinolaryngol 2002;68(5): 615-18.

9. Younis RT, Hesse SV, Anand VK. Evaluation of the utility and cost-effectiveness of obtaining histopathologic diagnosis on all routine tonsillectomy specimens. Laryngoscope 2001; 111(12):2116-69.

10. Ferreira JB, et al. Histopathologia de amidalas e adenoids de 154 pacientes operados. Rev Port Otorrinolaringol 2003; 41(1):35-39.

11. Moore KL. Embriologica clinica. 4th ed. Rio de Janeiro: Guanabara Koogan 1996;259.

12. Paradise JL. Tonsillectomy and adenoidectomy. In: Bluestone CD, Stool SE (Eds). Pediatric Otolaryngology (2nd ed). Philadelphia: WB Saunders 1990;2:915-26.

13. Feldmann H. 200 year history of tonsillectomy. Images from the history of otorhinolaryngology, highlighted by instruments from the collection of the German Medical History Museum in Ingolstadt. Laryngorhinootology 1997;76(12):751-60.

14. Waugh GE. A simple operation for the removal of tonsil with notes on 900 cases. Lancet 1909;1:1314-15.

15. Waugh GE. An operation for the excision of tonsils. Lancet 1909;2:572.

16. McClairen WC Jr, Strauss M. Tonsillectomy: A clinical study comparing the effects of local versus general anesthesia. Laryngoscope 1986 Mar;96(3):308-10.

17. Jebeles JA, Reilly JS, Gutierrez IF, Bradley Jr EL, Kissin I. The effect of preincisional infiltration of tonsils with bupivacaine on the pain following tonsillectomy under general anesthesia. Pain 1991;47:305-08.
18. Stuart JC, MacGregor FB, Cairns CS, Chandrachud HR. Peritonsillar infiltration with bupivacaine for paediatric tonsillectomy. Anaes and Intensive Care 1994;22:679-82.

19. Raj TB, Wickham MH. The effect of benzydamine hydrochloride (difflam) spray on post-tonsillectomy symptoms: A double blind study. The J of Laryngol Otol 1986;100:303-06.

20. Watters CH, Patterson CC, Mathews HML, Campbell W. Diclofenac sodium for post-tonsillectomy pain in children. Anesthesia 1988;43:641-43.

21. Freeman SB, Markwell JK. Sucralfate in alleviating posttonsillectomy pain. Laryngoscope 1992;102:1242-46.

22. Lombard B, Tomasi M, Charpentier, P, Drouet Y, Saigas P. Evaluation of transcutaneous electrostimulation in the management of post-tonsillectomy pain in adults. Rev LaryngolOtal-Rhinol-Bord 1996;117:89-92.

23. Kennedy KS, Strom CG. A comparison of postoperative bleeding incidence between general and local anesthesia tonsillectomies. Otolaryngol Head Neck Surg 1990 Jun;102 (6):654-57.

\section{ABOUT THE AUTHORS}

\section{Sudhir M Naik (Corresponding Author)}

Associate Professor, Department of ENT and Head and Neck Surgery KVG Medical College and Hospital, Kurunjibag, Sullia, Karnataka India, e-mail: sud223@gmail.com

\section{Sarika S Naik}

Senior Resident, Department of Anesthesia and Critical Care Narayana Hrudayalaya, Bengaluru, Karnataka, India

\section{S Ravishankara}

Associate Professor, Department of ENT and Head and Neck Surgery KVG Medical College and Hospital, Kurunjibag, Sullia, Karnataka, India

\section{Mohan K Appaji}

Professor and Head, Department of ENT and Head and Neck Surgery KVG Medical College and Hospital, Kurunjibag, Sullia, Karnataka, India

\section{MK Goutham}

Senior Resident, Department of ENT and Head and Neck Surgery, KVG Medical College and Hospital, Kurunjibag, Sullia, Karnataka, India

\section{Nonthombam Pinky Devi}

Senior Resident, Department of ENT and Head and Neck Surgery, KVG Medical College and Hospital, Kurunjibag, Sullia, Karnataka, India

\section{Annapurna S Mushannavar}

Senior Resident. Department of ENT and Head and Neck Surgery, KVG Medical College and Hospital, Kurunjibag, Sullia, Karnataka, India 